\title{
The Implementation of Total Quality Management in Greek Higher Education: The Case of Electronic Administrative Services
}

\author{
Anastasia Papanthymou ${ }^{1} \&$ Maria Darra ${ }^{1}$ \\ ${ }^{1}$ Department of Primary Education, University of the Aegean, Rhodes, Greece \\ Correspondence: Anastasia Papanthymou, Department of Primary Education, University of the Aegean, Rhodes, \\ Dimokratias 1, 85132, Greece. Tel: 30-694-833-9499. E-mail: premnt15043@rhodes.aegean.gr
}

Received: February 8, 2018

doi:10.5539/ies.v11n7p26
Accepted: March 15, $2018 \quad$ Online Published: June 28, 2018

URL: https://doi.org/10.5539/ies.v11n7p26

\begin{abstract}
The basic aim of this paper is to investigate the contribution of Total Quality Management (TQM) approach to improve the quality of electronic administrative services of the Department of Primary Education of the University of the Aegean. This research conducted during the second semester of the academic year 2016-17 and aims to implement specific TQM tools. A questionnaire responded by 128 undergraduate students were used to select the processes in which the TQM tools were implemented and an interview was conducted with two persons from the staff of the academic administration. The results of the survey show that the causes of failures were the human factor (students, academic staff and administrative staff) and weaknesses in the electronic services. Corrective actions are also proposed to correct to some extent the identified failures. Finally, the triptych-man, Information and Communication Technologies (ICT) and TQM contribute to the quality of electronic administrative services.
\end{abstract}

Keywords: higher education, total quality management, electronic administrative services, service quality

\section{Introduction}

\subsection{Introduction of the Problem}

Improving the quality of services provided to customers is widely implemented in the context of overall quality management in financial and administrative organizations. The higher education sector is one of the most recent service sectors where the TQM philosophy (Korre-Natsi, 2003; Farooq et al., 2007; Al-Omoush et al., 2015) is adopted and applied. Research so far shows that TQM and its tools are applicable and particularly useful in education. Some examples include research to highlight the importance of the TQM for improving the quality of higher education systems in various countries where bodies have been set up for assessing the quality of institutions (Farooq et al., 2007; Bhalla, 2012; Soomro et al., 2012). Other studies focus on identifying the most important dimensions of the quality of provided services (Chua, 2004; Lagrosen et al., 2004; Tsinidou et al., 2010; Saberi et al., 2015; Tarí \& Dick, 2016). Moreover, there are studies that focus on the results from the adoption of various TQM tools and practices (Korre-Natsi, 2003; Quinn et al., 2009; Ali \& Shastri, 2010; Nyaoga et al., 2010; Manola \& Tsarouhas, 2010; Pilava, 2012; Antoniadou \& Hatzipanayiotou, 2012; Zabadi, 2013; Oluseye et al., 2014; In'airat \& Al-Kassem, 2014; Alzhrani et al., 2016; Saha 2016).

\subsection{Importance of the Problem}

TQM has been little utilized in Greek higher education. The majority of TQM research aim to explore the legislative framework for quality, record quality assurance practices prevailing in higher education institutions and record the international trends about quality, internationally (Gika, 2004; Siminou, 2011; Kostitsa \& Spanaka, 2013; Oiconomidou, 2015). The research of using TQM tools to measure and improve the quality of higher education services is virtually non-existent. The research of Manola and Tsarouhas (2010), which investigated the contribution of specific TQM tools to improve the quality of higher education administrative services in a higher education institution is an exception. Their research has shown that the implementation of TQM tools, may find problems, propose solutions and help define procedures that will be useful to improve the quality of higher education administrative services. In addition, although there is much research related to TQM, there is not much literature on how to apply TQM to educational institutions (Saha, 2016) and it is noted that there is a need for empirical research to investigate significance and benefit of TQM practices (Tarí \& Dick, 2016). According to the previous, there is little relevant research into the use of the TQM tools to improve the quality of administrative 
services provided to students in Greece and by the writing of this study. This study is being carried out to address these two gaps by contributing to further investigate the effectiveness of the TQM to improve the quality of higher education. The answers to the research questions of the present study aim to highlight a different aspect of the use of TQM in higher education and encourage more researchers to explore the effectiveness of TQM and its tools.

\subsection{Literature Review}

Through an expanded literature review, 41 studies of the quality of services provided by higher education institutions in Greek and international area have been identified, focusing on the benefits of TQM, the critical success factors, the quality tools or models and the evaluation of electronic services in higher education. The following paragraphs summarize the most important findings of these studies. Studies highlight the importance of TQM as a modern management approach, with reference to the benefits of its implementation, the continuous improvement of the quality of education (Korre-Natsi, 2003; Farooq et al., 2007; Oiconomidou, 2015; Alzhrani et al., 2016), the improvement of the administrative services (Manola \& Tsarouhas, 2010), the reinforcement of employee morale, teamwork, improvement of the quality perceived by the customer (Ali \& Shastri, 2010; Zabadi, 2013) and generally the overall qualitative upgrading of higher education institutions (Antoniadou \& Hatzipanayiotou, 2012). In addition, other benefits from TQM implementation are strengthening of the competitiveness of a higher education institution and increase of employees' creativity (Todorut, 2013).

There are critical factors that influence the successful implementation of TQM on higher education institutions. These are employee involvement, customer focus, satisfaction (Zakuan et al., 2012; Zubair, 2013; Al Omoush et al., 2015, Saberi et al., 2015; Nadin \& Al-Hinai, 2016) and commitment of leadership (Davies, 2008; Zakuan et al., 2012; Militaru et al., 2013; Zubair, 2013; Al Omoush et al., 2015) namely transformational leadership which seems to have a significant positive impact on TQM practices (Argia \& Ismail, 2013). Furthermore, the mobilization and efficient communication of the members of a higher education institution are some of the key pillars for successful implementation of TQM (Taskov \& Mitreva, 2014).

Higher education can implement TQM through a variety of tools. Ishikawa diagram, which is a tool of TQM, was used with Multicriteria Satisfaction Analysis to assess the services of a higher institution, including the administrative services (Bouris \& Dimas, 2009), where the sub-criterion "Waiting-service time" of the quality dimension "Administrative Support" was the most significant sub-criterion for the administrative services. Failure Mode Effects Analysis (FMEA), Ishikawa diagram and Pareto analysis were applied to administrative services and underlined problems, proposed solutions, and defined those processes that were necessary for the functioning of institutions. In addition, the noticed failures were linked to the administrative staff, the students, the academic staff and finally the department's infrastructure (Manola \& Tsarouhas, 2010). Among several questionnaires, such as Servqual, or scales such as HedPERF and SerVPERF, HedPERF has supremacy (Abdullah, 2006), and generally questionnaires or quality models have been used to evaluate services and have been adapted to the needs of assessment of each institution, such as HEQAM evaluation model, which also includes criteria for electronic services (Noaman et al., 2013) gave important guidance to the University leadership to meet the required quality of service and one of its strategic goals that was to become an electronic university with less bureaucracy.

In the Greek area, a study on the evaluation of the students' electronic services provided by a higher education institution, showed that students use very much the internet applications, and all of the students agree on the need for a wi-fi network throughout the University (Bakos, 2013), Also, related research of the expectations and perceptions of the students and the academic staff about the quality of the services provided by the university showed that important factors of satisfaction are the correct information of students, at any time and from anywhere, the efficiency and availability of the website (Cerri, 2014).

\subsection{Theoretical Framework}

The review of the literature has shown that a range of quality management models developed for industry has been used in higher education worldwide. According to Cruickshank (2003, cited in Zabadi, 2013), the most commonly used international approach is TQM.

According to Harry (1994 cited in Zakuan et al., 2012) there are three general approaches to TQM in higher education. Initially, there is a customer focus where the idea of service to students is promoted through staff training and development that promotes student's choices and autonomy. The second focuses on staff, specifically on enhancing the participation of all members in the efficiency of the institution's operation and in defining its policies and priorities. The third focuses on service specifications and seeks to ensure compliance with them at certain measurable points of educational processes.

Thiagarajan (1996 cited in Nadim \& Al-Hinai, 2016) points out that the TQM is the most important quality 
approach that can measure the quality of higher education. Zink and Schmidt (1995 cited in Simeonidou, 2015) points out that the goals that a university set, should relate to all its activities, and this can be achieved through a strategic planning process that TQM offers. There are several reasons for implementing TQM in higher education. These are increasing institution's credibility, attracting students, donations, fund subsidies, smooth internal operation, advanced administrative methods, increasing employee morale and motivation, customer satisfaction, harmonization with international legal framework, increased employers' interest, preservation of standards, competition from institutions, and display of institution and strengthening of the prestige of a higher institution.

Quality dimensions are the quality criteria on which the customer evaluates the provided services (Korre-Natsi, 2003). Specifically, quality dimensions of electronic administrative services are TQM, ease of access, safety, reliability, understanding, skills and knowledge of employees, appropriate equipment, willingness to service and communication.

\subsection{Research Questions}

The basic aim of this study is to investigate the contribution of the TQM approach to the improvement of the quality of electronic services provided by the secretariat of a higher education institution in Greece, specifically the Department of Primary Education of the University of the Aegean. The study aims at: a. to explore the student's views about the importance of the provided electronic administrative services, the extent to which students are satisfied with the services and the problems with these services, b. to implement specific TQM tools (Ishikawa or Cause-effect diagram, FMEA and Pareto analysis), to identify potential problems and failures in electronic administrative services, to propose corrective actions and record the expected improvements and results after the implementation of the corrective actions. This study aims to answer to the following research questions:

1) How do the students who are part of this research population assess the importance of the provided electronic administrative services?

2) To what extent do the students who are part of this research population consider that they are satisfied with the provided electronic administrative services?

3) What problems do the students who are part of this research population have with the provided electronic administrative services?

4) To what extent and how the introduction and implementation of specific TQM tools can contribute to improvement of quality of the provided electronic administrative services?

\section{Method}

\subsection{Type of Research}

This research is interventionist because its purpose was the intervention through the implementation of corrective actions to improve the problematic functions of the electronic administrative services and applicable as its results were practically utilized. Based on the type of collected empirical data, the research is quantitative. In addition, the research is fieldwork because of the questionnaire and the interview with the presence of the researcher and finally the research is sampling because of the number of the examined persons (Paraskevopoulos, 1993). The sampling survey gives us flexibility in our analysis because it allows us to ask many questions about a certain issue (Babbie, 2011).

\subsection{The Sample of the Research}

The sample of the research consisted of 128 undergraduate students of the Department of Primary Education of the University of the Aegean. About $20 \%$ of the number of active enrolled students per year of study was used for the research which is a representative sample. Questionnaires were shared to 128 undergraduate students of the department from March 01, 2017, to March 09, 2017. Previously, a pilot survey with ten undergraduate students was carried out from 21 to 24 February 2017.

\subsection{Research Design}

It was decided to implement FMEA in the following electronic administrative services: the administrative service Students web, the administrative service of issuing of academic identity cards, the Eudoxos administrative service of academic books' registration and the official website of the department. The most important services for the students and these services that had the most failures were collected. In total, we performed seven failure analyses. Four analyses for the administrative service Students web, one analysis for the administrative service of issuing of academic identity cards, one analysis for the Eudoxos administrative service of academic books' registration, and one analysis for the official website of the department. 
The choice of functions to which FMEA was applied based on the results of the student questionnaire and the interview with the two persons of the administrative staff. Moreover, the effectiveness of the corrective actions and the significance of the failures for the most efficient and effective function of the department were investigated. Additionally, a "Vision Statement" was made after the interview and other quality tools were used, such as the Ishikawa diagram and the Pareto analysis. Research design is presented in Figure 1.

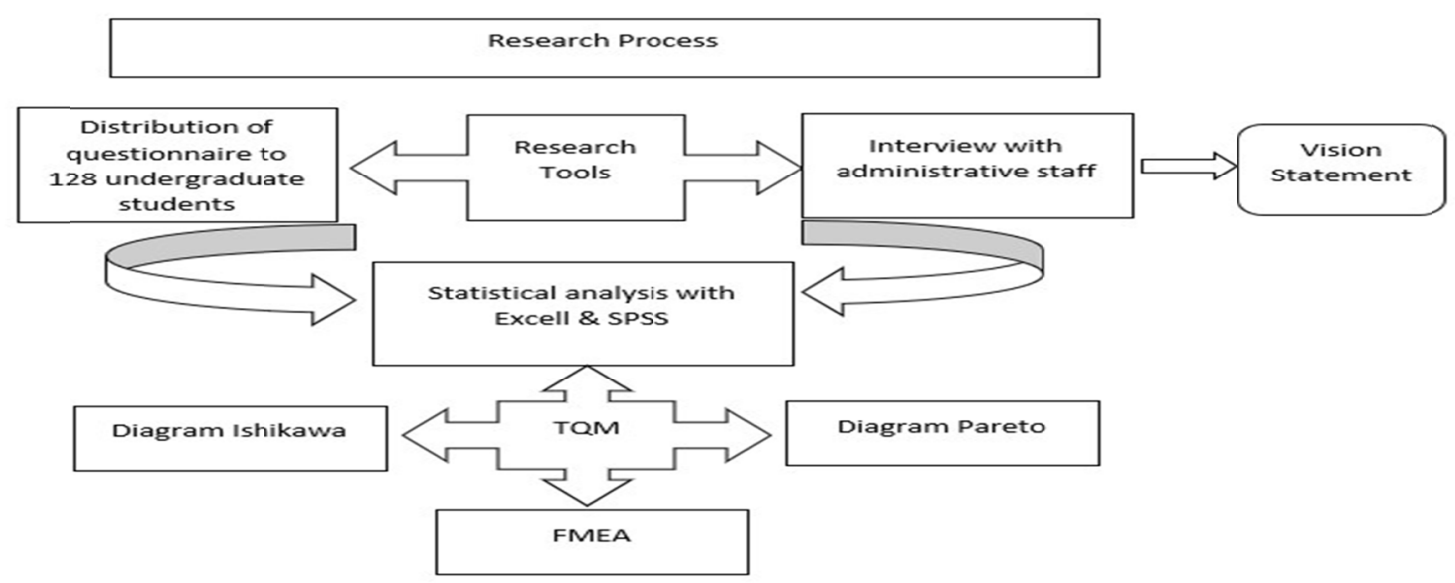

Figure 1. Research design

\subsection{Data Collection Tools}

The questionnaire that was given to the undergraduate students of the University of the Aegean, is self-designed and consists of two parts. The first part relates to the gender of the respondents and their year of study. The second part contains three questions. The first question is ordinal question and measures the assessment of the importance of electronic administrative services by the students. The second question is 5-point Likert scale question and measures the degree of satisfaction of the students with the provided electronic administrative services and the third question is multiple choices and concerns the problems with electronic administrative services that students encountered. The internal relevance of the questionnaire is ensured, as the Cronbach's alpha index value is 0.915 and value greater than 0.70 is acceptable. The statistical processing of the questionnaire and the interview was done using the Microsoft Excel program and IBM SPSS Statistics 20.

\section{Results}

\subsection{Sample Data}

Female students represent the largest percentage of enrolled students (78.55\%), while male students represent only $(21.45 \%)$. Female students were $(85.94 \%)$ of the number of students who took part in the survey, while male students were only (14.06\%). Additionally, almost (21.62\%) of the students participated in the survey. The percentage of the students who took part in the survey per year of study was $(21.66 \%)$ from the first year, $(20.86 \%)$ from the second year, $(24.30 \%)$ from the third year and (20.61\%) from the fourth year.

\subsection{Research Question 1: Degree of Importance of Provided Electronic Administrative Services to Students}

In question (3) "Which of the following electronic services is more important to you? (Sorted by the order of

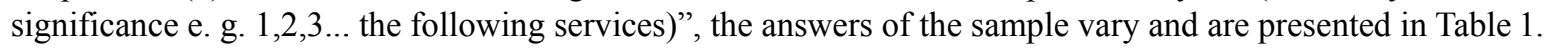


Table 1. Distribution of frequencies, relative percentages (\%) and means of evaluation of the importance of electronic administrative services

\begin{tabular}{|c|c|c|c|c|c|c|c|}
\hline Evaluation of the importance of electronic administrative services & Mean & $\begin{array}{c}1 \text { st } \\
\text { choice }\end{array}$ & $\begin{array}{c}2^{\text {nd }} \\
\text { choice }\end{array}$ & $\begin{array}{c}3^{\text {rd }} \\
\text { choice }\end{array}$ & $\begin{array}{c}4^{\text {th }} \\
\text { choice }\end{array}$ & $\begin{array}{c}5^{\text {th }} \\
\text { choice }\end{array}$ & $\begin{array}{c}6^{\text {th }} \\
\text { choice } \\
\end{array}$ \\
\hline \multirow{2}{*}{ Website of the department } & \multirow{2}{*}{1.85} & 59 & 29 & 14 & 9 & 2 & 1 \\
\hline & & $46.1 \%$ & $22.7 \%$ & $10.9 \%$ & $7.0 \%$ & $1.6 \%$ & $0.8 \%$ \\
\hline \multirow{2}{*}{ Administrative service Students web } & \multirow{2}{*}{2.00} & 38 & 56 & 11 & 0 & 9 & \multirow{2}{*}{$0.0 \%$} \\
\hline & & $29.7 \%$ & $43.8 \%$ & $8.6 \%$ & $0.0 \%$ & $7.0 \%$ & \\
\hline \multirow[b]{2}{*}{ Eudoxos administrative service of academic books' registration } & \multirow[b]{2}{*}{3.34} & 4 & 12 & 56 & 27 & 13 & \multirow{2}{*}{$1.6 \%$} \\
\hline & & $3.1 \%$ & $9.4 \%$ & $43.85 \%$ & $21.1 \%$ & $10.2 \%$ & \\
\hline \multirow{2}{*}{ Administrative service of issuing of academic identity card } & \multirow{2}{*}{3.70} & 10 & 6 & 19 & 57 & 17 & 5 \\
\hline & & $7.8 \%$ & $4.7 \%$ & $14.8 \%$ & $44.5 \%$ & $13.3 \%$ & $3.9 \%$ \\
\hline \multirow{2}{*}{ Administrative service of application for housing benefits } & \multirow{2}{*}{4.65} & 1 & 9 & 8 & 16 & 57 & 23 \\
\hline & & $0.8 \%$ & $7.0 \%$ & $6.3 \%$ & $12.55 \%$ & $44.5 \%$ & $18.0 \%$ \\
\hline \multirow{2}{*}{ Communication platform uniway for mobiles } & \multirow{2}{*}{5.44} & 2 & 2 & 7 & 5 & 15 & 83 \\
\hline & & $1.6 \%$ & $1.6 \%$ & $5.5 \%$ & $3.9 \%$ & $11.7 \%$ & $64.8 \%$ \\
\hline
\end{tabular}

\subsection{Research Question 2: Degree of Satisfaction of Students with Electronic Administrative Services}

In question (4) "To what extent are you satisfied with the following electronic administrative services?". The answers of the sample vary and are presented in Table 2.

Table 2. Distribution of frequencies, relative percentages (\%), means and standard deviation of satisfaction with electronic administrative services

\begin{tabular}{|c|c|c|c|c|c|c|c|}
\hline $\begin{array}{l}\text { Degree of satisfaction with the electronic } \\
\text { administrative services }\end{array}$ & Mean & $\begin{array}{l}\text { Standard } \\
\text { Deviation }\end{array}$ & $\begin{array}{l}\text { Very } \\
\text { much }\end{array}$ & Very & Neutral & Not very & Not at all \\
\hline \multirow{2}{*}{ Electronic issuing of certificates } & \multirow{2}{*}{3.35} & \multirow{2}{*}{1.049} & 21 & 31 & 51 & 9 & 5 \\
\hline & & & $16.5 \%$ & $24.4 \%$ & $40.2 \%$ & $15.0 \%$ & $3.9 \%$ \\
\hline \multirow{2}{*}{ Course registration in Students web } & \multirow{2}{*}{3.95} & \multirow{2}{*}{0.744} & 26 & 75 & 20 & 6 & 0 \\
\hline & & & $20.5 \%$ & $59.1 \%$ & $15.7 \%$ & $4.7 \%$ & $0.0 \%$ \\
\hline \multirow{2}{*}{ Announcement of grades in Students web } & \multirow{2}{*}{3.76} & \multirow{2}{*}{0.990} & 30 & 53 & 30 & 11 & 3 \\
\hline & & & $23.6 \%$ & $41.7 \%$ & $23.6 \%$ & $8.7 \%$ & $2.4 \%$ \\
\hline \multirow{2}{*}{$\begin{array}{l}\text { Announcements of program's courses and } \\
\text { exams on the official website }\end{array}$} & \multirow{2}{*}{3.81} & \multirow{2}{*}{0.957} & 35 & 45 & 36 & 10 & 1 \\
\hline & & & $27.6 \%$ & $35.4 \%$ & $28.3 \%$ & $7.9 \%$ & $0.8 \%$ \\
\hline \multirow{2}{*}{$\begin{array}{l}\text { Announcements of course postponement at } \\
\text { the official website }\end{array}$} & \multirow{2}{*}{3.24} & \multirow{2}{*}{1.269} & 27 & 26 & 37 & 24 & 13 \\
\hline & & & $21.3 \%$ & $20.5 \%$ & $29.1 \%$ & $18.9 \%$ & $10.2 \%$ \\
\hline \multirow{2}{*}{$\begin{array}{l}\text { Eudoxos administrative service of academic } \\
\text { books' registration }\end{array}$} & \multirow{2}{*}{3.76} & \multirow{2}{*}{0.990} & 27 & 60 & 27 & 8 & 5 \\
\hline & & & $21.3 \%$ & $47.2 \%$ & $21.3 \%$ & $6.3 \%$ & $3.9 \%$ \\
\hline \multirow{2}{*}{$\begin{array}{l}\text { Administrative service of issuing of } \\
\text { academic identity cards }\end{array}$} & \multirow{2}{*}{3.59} & \multirow{2}{*}{1.094} & 24 & 55 & 28 & 12 & 8 \\
\hline & & & $18.9 \%$ & $43.3 \%$ & $22.0 \%$ & $9.4 \%$ & $6.3 \%$ \\
\hline \multirow{2}{*}{$\begin{array}{l}\text { Administrative service of application for } \\
\text { housing benefits }\end{array}$} & \multirow{2}{*}{2.73} & \multirow{2}{*}{1.325} & 12 & 26 & 35 & 17 & 33 \\
\hline & & & $9.8 \%$ & $21.1 \%$ & $28.5 \%$ & $13.8 \%$ & $26.8 \%$ \\
\hline \multirow{2}{*}{$\begin{array}{l}\text { Communication platform uniway for } \\
\text { mobiles }\end{array}$} & \multirow{2}{*}{2.17} & \multirow{2}{*}{1.239} & 6 & 14 & 25 & 24 & 51 \\
\hline & & & $5.0 \%$ & $11.7 \%$ & $20.8 \%$ & $20.0 \%$ & $42.5 \%$ \\
\hline
\end{tabular}

\subsection{Research Question 3: Problems with Electronic Administrative Services}

In question (5) "Which of the following problems with the electronic administrative services have you encountered during your studies?" The answers of the sample vary and are presented in Table 3. 
Table 3. Distribution of frequencies, relative percentages (\%) of problems with electronic administrative services

\begin{tabular}{lc}
\hline Problems with electronic administrative services & \\
\hline Delay of grades' announcement & 105 \\
& $82.0 \%$ \\
Delay of the issuing of certificates & 19 \\
& $14.8 \%$ \\
Mistakes regarding course grades & 30 \\
& $23.4 \%$ \\
Mistakes of the issuing of certificates & 5 \\
& $3.9 \%$ \\
Mistakes regarding course registration & 11 \\
& $8.6 \%$ \\
Mistakes regarding academic books' registration & 17 \\
& $13.3 \%$ \\
Unsuccessful course registration & 27 \\
& $21.1 \%$ \\
Unsuccessful academic books' registration & 19 \\
& $14.8 \%$ \\
Unsuccessful issuing of academic identity cards & 12 \\
Unsuccessful issuing of certificates & $9.4 \%$ \\
\hline
\end{tabular}

3.5 Research Question 4: Implementation and Contribution of TQM Tools to Improve the Quality of Electronic Administrative Services

\subsubsection{Results Based on TQM Tool-Ishikawa or Cause and Effect Diagram}

Ishikawa diagrams for the four most important electronic administrative services in which failures were observed are presented in Figures 2,3,4,5.

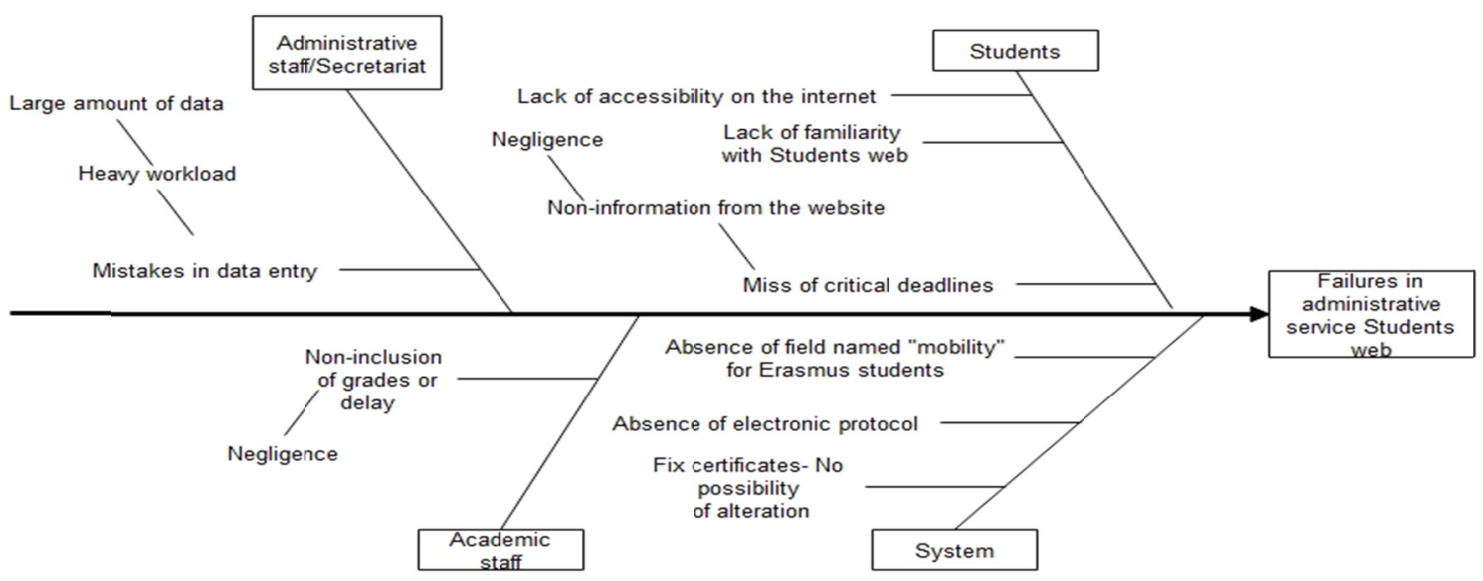

Figure 2. Ishikawa diagram for failures in administrative service students web 


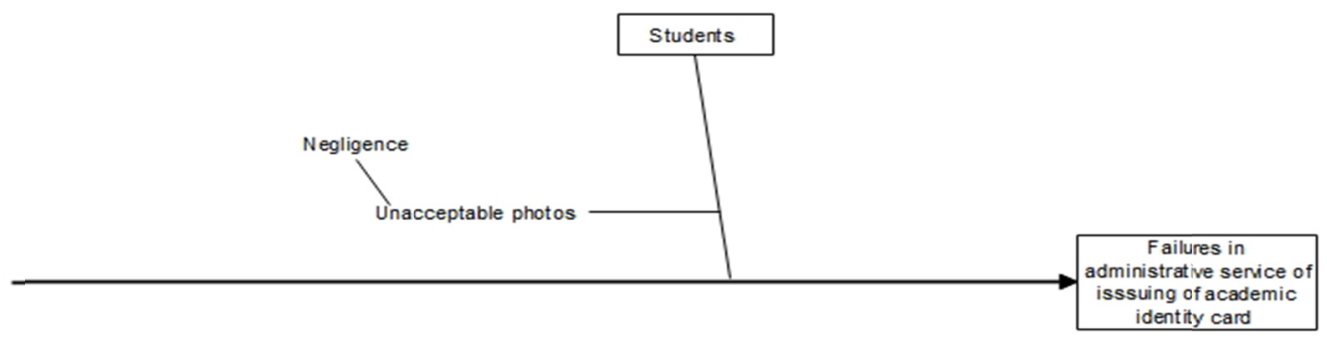

Figure 3. Ishikawa diagram for failures in administrative service of issuing of academic identity card

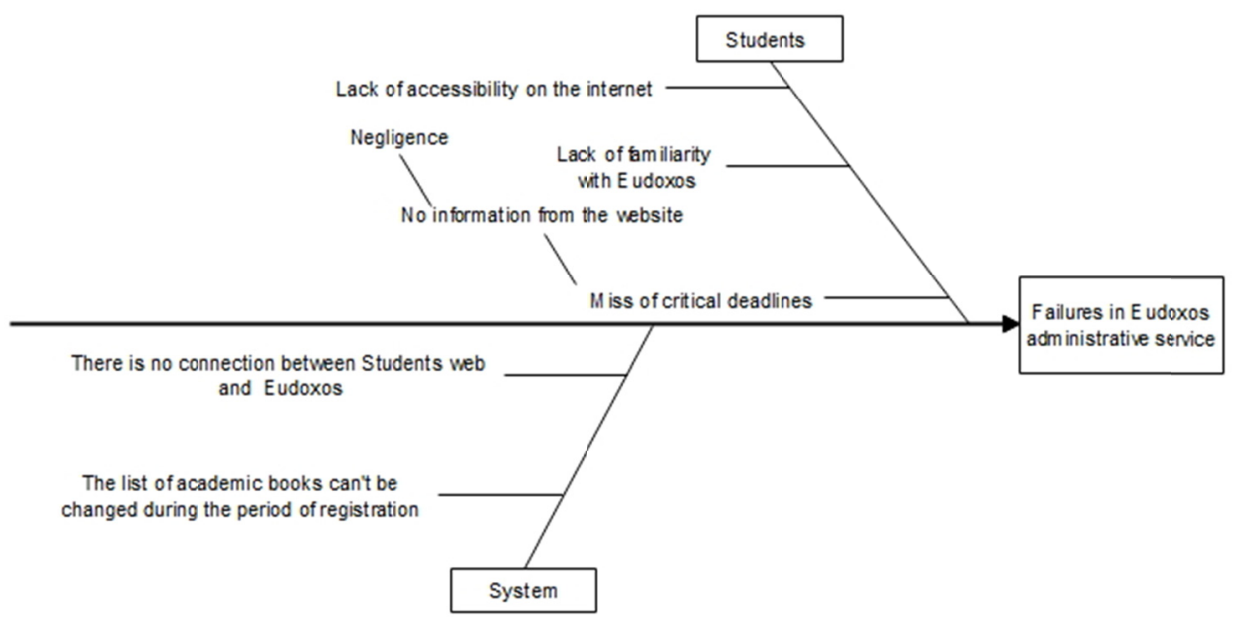

Figure 4. Ishikawa diagram for failures in Eudoxos administrative service for academic books' registration

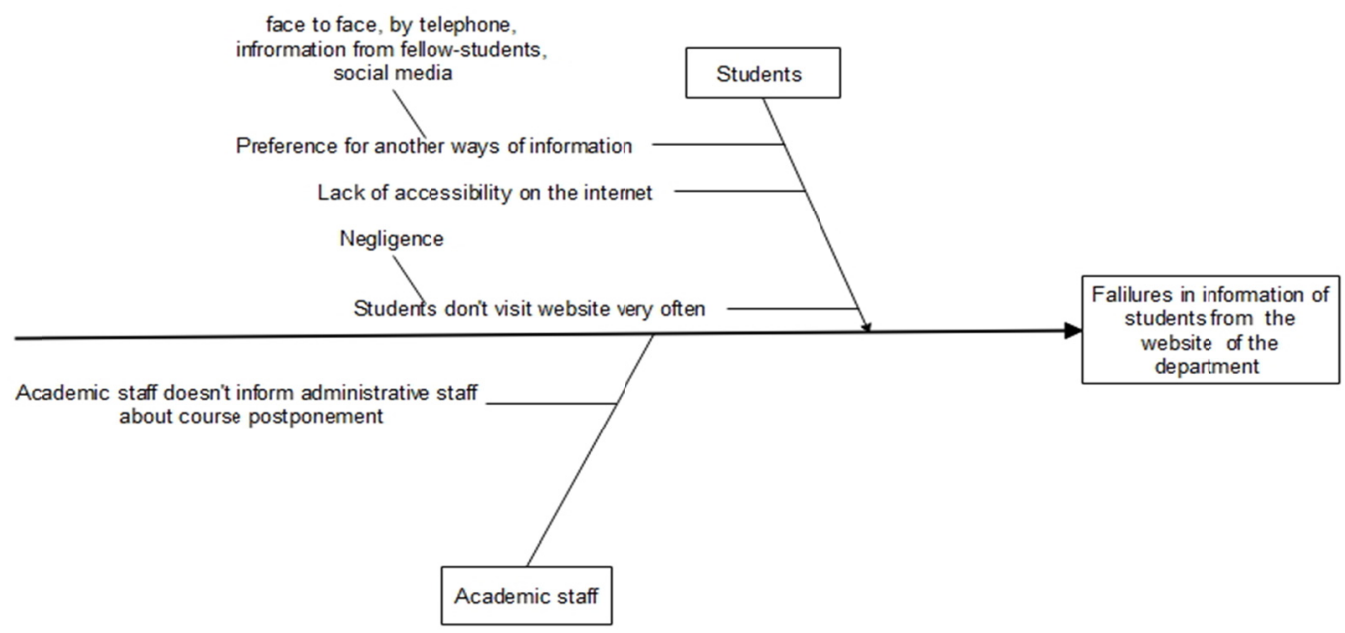

Figure 5. Ishikawa diagram for failures in information of students from the website of the department

\subsubsection{Results Based on TQM Tool-Pareto Diagram or Analysis}

FMEA was used to calculate the Risk Priority Number (RPN) that is presented in Figure 6 for the selected electronic administrative services. FMEA is presented in Table 4. 


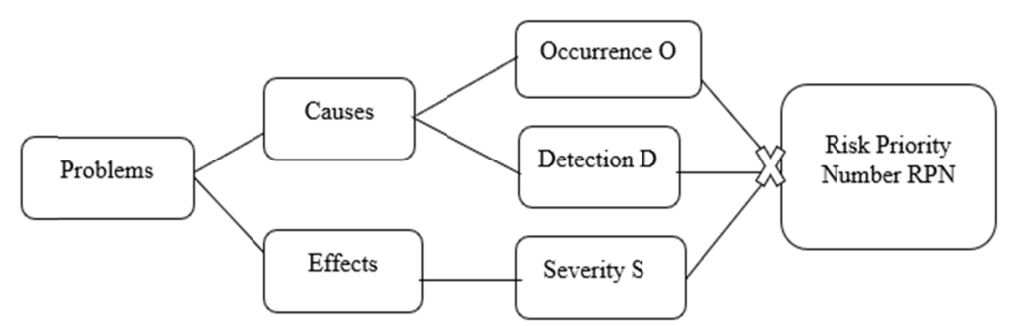

Figure 6. Procedure for calculating RPN

Table 4. FMEA for electronic administrative services of Primary Education of the University of the Aegean

\begin{tabular}{|c|c|c|c|c|c|c|c|c|c|c|c|c|c|}
\hline \multirow[b]{2}{*}{$\begin{array}{l}\text { Administrat } \\
\text { ive service }\end{array}$} & \multirow{2}{*}{$\begin{array}{c}\text { Potential } \\
\text { Failure } \\
\text { Mode }\end{array}$} & \multirow{2}{*}{$\begin{array}{l}\text { Potential } \\
\text { Effect(s) of } \\
\text { Failure }\end{array}$} & \multirow[b]{2}{*}{$\mathrm{S}$} & \multirow{2}{*}{$\begin{array}{l}\text { Potential } \\
\text { Cause(s) of } \\
\text { Failure }\end{array}$} & \multirow[b]{2}{*}{$\mathrm{O}$} & \multirow{2}{*}{$\begin{array}{l}\text { Current } \\
\text { Process } \\
\text { Control }\end{array}$} & \multirow[b]{2}{*}{$\mathrm{D}$} & \multirow[b]{2}{*}{ ฉa } & \multirow{2}{*}{$\begin{array}{l}\text { Recommend } \\
\text { ed/Correctiv } \\
\text { e Action(s) }\end{array}$} & \multicolumn{4}{|c|}{ Action Results } \\
\hline & & & & & & & & & & $\mathrm{S}$ & $\mathrm{O}$ & $\mathrm{D}$ & ż \\
\hline \multirow{6}{*}{$\begin{array}{c}\text { Students } \\
\text { web }\end{array}$} & \multirow{4}{*}{$\begin{array}{l}\text { Unsuccessf } \\
\text { ul course } \\
\text { registration } \\
\text { or mistakes } \\
\text { regarding } \\
\text { course } \\
\text { registration }\end{array}$} & \multirow{4}{*}{$\begin{array}{c}\text { Delay of } \\
\text { studies }\end{array}$} & \multirow{4}{*}{8} & $\begin{array}{c}\text { Mistakes } \\
\text { regarding data } \\
\text { entry because } \\
\text { of large } \\
\text { amount of data } \\
\text { from } \\
\text { administrative } \\
\text { staff } \\
\end{array}$ & 5 & Simulation & 4 & $\stackrel{8}{0}$ & $\begin{array}{c}\text { More } \\
\text { attention to } \\
\text { data entry } \\
\text { and/or } \\
\text { control by } \\
\text { more } \\
\text { persons }\end{array}$ & 8 & 3 & 4 & ஃ \\
\hline & & & & $\begin{array}{c}\text { Lack of } \\
\text { students' } \\
\text { familiarity with } \\
\text { Students web }\end{array}$ & 9 & \multirow{3}{*}{$\begin{array}{l}\text { Discussion } \\
\text { with } \\
\text { students }\end{array}$} & 5 & $\underset{ల}{8}$ & $\begin{array}{l}\text { Information } \\
\text { of students } \\
\text { about the } \\
\text { use of } \\
\text { Students } \\
\text { web }\end{array}$ & 8 & 6 & 5 & $\stackrel{\stackrel{+}{\sim}}{\sim}$ \\
\hline & & & & $\begin{array}{c}\text { Lack of } \\
\text { accessibility on } \\
\text { the Internet }\end{array}$ & 9 & & 5 & $\underset{m}{8}$ & $\begin{array}{c}\text { Internet } \\
\text { access } \\
\text { throughout } \\
\text { university/e } \\
\text { xistence of } \\
\text { wi-fi } \\
\end{array}$ & 8 & 5 & 5 & $\underset{\sim}{\stackrel{D}{2}}$ \\
\hline & & & & $\begin{array}{c}\text { Missing of } \\
\text { critical } \\
\text { deadlines } \\
\text { because of not } \\
\text { information } \\
\text { from the } \\
\text { website } \\
\text { (negligence of } \\
\text { students) } \\
\end{array}$ & 8 & & 5 & స్ & $\begin{array}{l}\text { Students' } \\
\text { awareness-r } \\
\text { aising }\end{array}$ & 8 & 6 & 5 & $\stackrel{9}{7}$ \\
\hline & $\begin{array}{l}\text { Delay or } \\
\text { non- } \\
\text { inclusion of } \\
\text { grades }\end{array}$ & $\begin{array}{c}\text { Students are } \\
\text { dissatisfied }\end{array}$ & 8 & $\begin{array}{c}\text { Negligence } \\
\text { from academic } \\
\text { staff }\end{array}$ & 9 & $\begin{array}{l}\text { Information } \\
\text { from } \\
\text { students }\end{array}$ & 5 & $\underset{n}{8}$ & $\begin{array}{l}\text { Recommend } \\
\text { ation to } \\
\text { academic } \\
\text { staff }\end{array}$ & 8 & 5 & 5 & 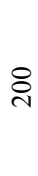 \\
\hline & $\begin{array}{l}\text { Wrong with } \\
\text { diploma } \\
\text { supplement }\end{array}$ & $\begin{array}{c}\text { Students are } \\
\text { dissatisfied }\end{array}$ & 8 & $\begin{array}{l}\text { Absence of a } \\
\text { field named } \\
\text { "mobility" for }\end{array}$ & & $\begin{array}{l}\text { Information } \\
\text { from } \\
\text { students }\end{array}$ & 5 & \& & $\begin{array}{l}\text { Existence of } \\
\text { a field } \\
\text { named }\end{array}$ & 8 & 3 & 5 & さิ \\
\hline
\end{tabular}




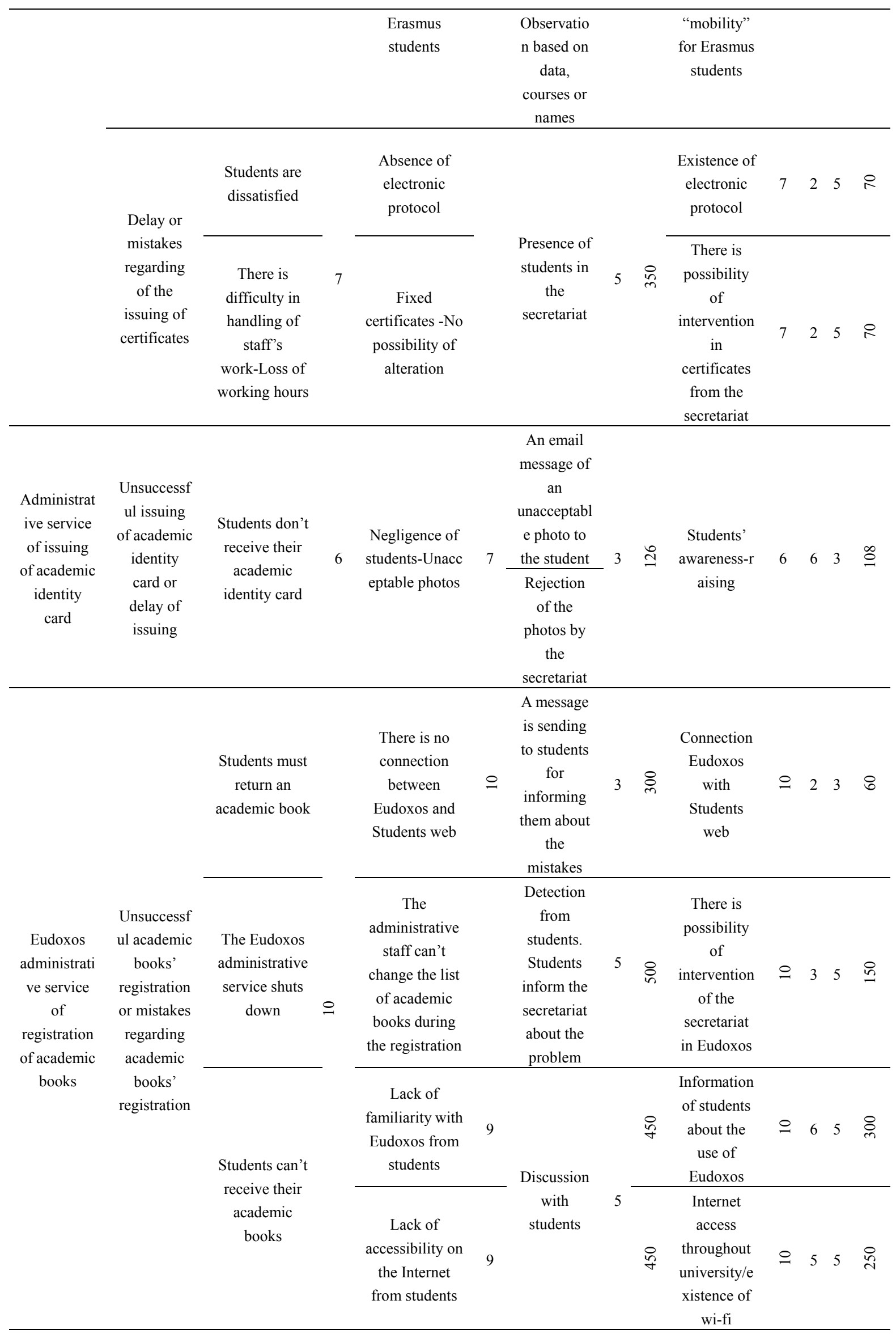




\begin{tabular}{|c|c|c|c|c|c|c|c|c|c|c|c|c|c|}
\hline & & & & $\begin{array}{l}\text { Miss of critical } \\
\text { deadlines } \\
\text { because of lack } \\
\text { of information } \\
\text { from the } \\
\text { website } \\
\text { (negligence of } \\
\text { students) }\end{array}$ & 8 & & & \& & $\begin{array}{l}\text { Students' } \\
\text { awareness-r } \\
\text { aising }\end{array}$ & $\stackrel{\varrho}{ }$ & 6 & 5 & \&্ল \\
\hline \multirow{3}{*}{$\begin{array}{l}\text { Information } \\
\text { of students } \\
\text { from the } \\
\text { website of } \\
\text { the } \\
\text { department }\end{array}$} & \multirow{3}{*}{$\begin{array}{l}\text { Inadequate/ } \\
\text { poor } \\
\text { information } \\
\text { of students } \\
\text { from the } \\
\text { website }\end{array}$} & \multicolumn{2}{|l|}{$\begin{array}{l}\text { Students go to } \\
\text { a lesson that } \\
\text { has been } \\
\text { postponed } \\
\text { (complaints of } \\
\text { students) }\end{array}$} & $\begin{array}{l}\text { Academic staff } \\
\text { doesn't inform } \\
\text { administrative } \\
\text { staff about } \\
\text { course } \\
\text { postponement }\end{array}$ & 9 & $\begin{array}{c}\text { Secretariat } \\
\text { communica } \\
\text { te with } \\
\text { academic } \\
\text { staff after } \\
\text { its } \\
\text { information } \\
\text { from } \\
\text { students }\end{array}$ & 5 & $\frac{n}{m}$ & $\begin{array}{l}\text { Recommend } \\
\text { ation to } \\
\text { academic } \\
\text { staff to } \\
\text { inform } \\
\text { administrati } \\
\text { ve staff } \\
\text { about course } \\
\text { postponeme } \\
n \\
\end{array}$ & 7 & 5 & 5 & $\stackrel{n}{I}$ \\
\hline & & \multirow{2}{*}{$\begin{array}{l}\text { Administrative } \\
\text { staff of } \\
\text { secretariat } \\
\text { must inform } \\
\text { students (loss } \\
\text { of working } \\
\text { hours) }\end{array}$} & \multirow{2}{*}{ 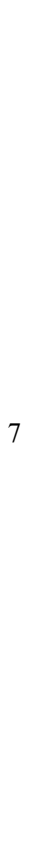 } & $\begin{array}{l}\text { Preference for } \\
\text { other ways of } \\
\text { information }\end{array}$ & 7 & \multirow{2}{*}{$\begin{array}{l}\text { Discussion } \\
\text { with } \\
\text { students }\end{array}$} & \multirow[b]{2}{*}{5} & $\stackrel{n}{\sim}$ & $\begin{array}{l}\text { Students' } \\
\text { awareness-r } \\
\text { aising }\end{array}$ & 7 & 5 & 5 & $\stackrel{n}{I}$ \\
\hline & & & & $\begin{array}{c}\text { Lack of } \\
\text { accessibility on } \\
\text { the Internet }\end{array}$ & 9 & & & $\frac{n}{m}$ & $\begin{array}{c}\text { Internet } \\
\text { access } \\
\text { throughout } \\
\text { university/e } \\
\text { xistence of } \\
\text { wi-fi }\end{array}$ & 7 & 5 & 5 & $\stackrel{2}{I}$ \\
\hline
\end{tabular}

\subsubsection{Results based on TQM tool-Pareto diagram or analysis}

The Pareto diagram presents the causes with the highest RPN numbers. Out of the total seventeen (17) causes of recorded failures, 13 are shown in the diagram and 10 of these have RPN greater than 340 and are responsible for $80 \%$ of total failures. Pareto diagram is presented in Figure 7. 


\section{[Diagram Pareto for the most important failures ]}

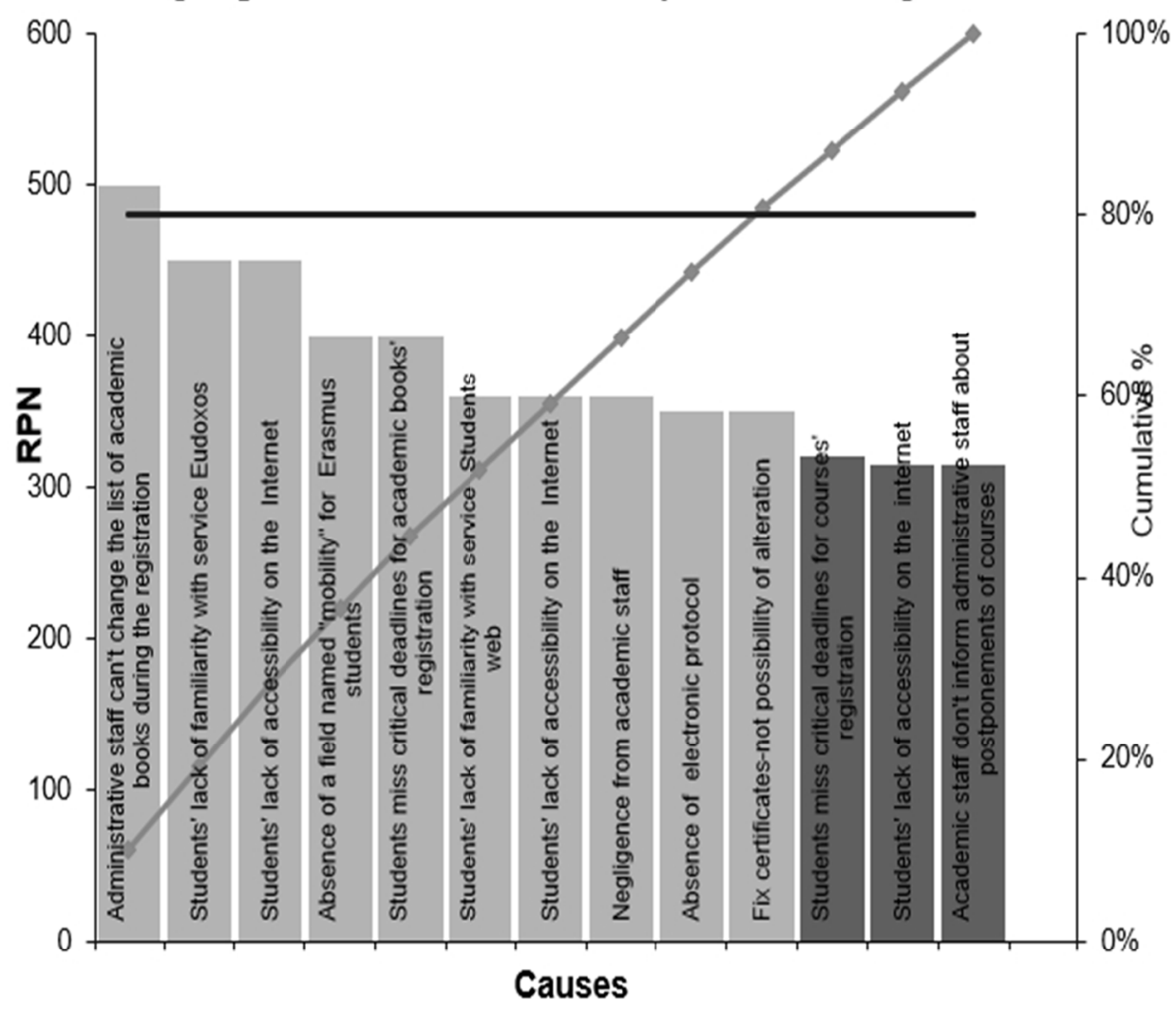

Vital Few Useful Many $\quad \longrightarrow$ Cumulative $\% \quad$ Cut Off $\%$

Figure 7. Pareto diagram for the most important failures

\section{Discussion}

\subsection{Sample Data}

The number of female students is much higher than that of male students. Specifically, male students represent only $(21.45 \%)$ of enrolled students while female students represent a much larger percentage $(78.55 \%)$ of enrolled students. This explains the low percentage of participating male students $(14.06 \%)$ in the survey against the very large percentage of participating female students $(85.94 \%)$.

\subsection{Research Question 1: Degree of Importance of Provided Electronic Administrative Services to Students}

The website of the department is the most important administrative service for students (mean=1.85), followed by the administrative service Students web (mean=2.00), the Eudoxos administrative service (mean=3.34), the administrative service of issuing of academic identity cards (mean=3.70), the administrative service of application for housing benefits (mean=4.65) and the communication platform uniway for mobiles (mean=5.44).

\subsection{Research Question 2: Degree of Satisfaction of Students with Electronic Administrative Services}

Students are primarily satisfied with the course registration in Students web (mean=3.95), followed by the announcements of program's courses and exams on the official website of the department (mean=3.81), the announcement of grades on Students web (mean=3.76) and the Eudoxos administrative service of academic books' registration (mean=3.76), the administrative service of issuing of academic identity cards (mean=3.59), the electronic issuing of certificates (mean=3.35), the announcements of course postponement at the official website of the department (mean=3.24), the administrative service of application for housing benefits (mean=2.73), and the communication platform uniway for mobiles (mean=2.17). 


\subsection{Research Question 3: Problems with Electronic Administrative Services}

The problems with provided electronic administrative services that were identified by the students are the delay of grades' announcement $(82.0 \%)$, the mistakes regarding courses' grades $(23.4 \%)$, the unsuccessful course registration $(21.1 \%)$, the delay of the issuing of certificates $(14.8 \%)$, the unsuccessful academic books' registration $(14.8 \%)$, the mistakes regarding academic books' registration $(13.3 \%)$, the unsuccessful issuing of academic identity cards $(9.4 \%)$, the mistakes regarding course registration $(8.6 \%)$, the unsuccessful issuing of certificates $(7.0 \%)$ and finally the mistakes regarding of the issuing of certificates $(3.9 \%)$.

From the above findings it seems that even though students are more satisfied with the services which are more important to them, they also notice failures in these services. Therefore, there is room for improvement despite their satisfaction due to the great importance these services have for them. Among these services are the website of the department, the administrative service Students web and the Eudoxos administrative service. These findings are also confirmed by the findings of another relevant research (Bakos, 2013), according to which students agreed of the existence of a wi-fi wireless network. Also, the study of Manola \& Tsarouhas (2010) showed that students encountered similar internet access problems and asked for phone service, something that we observed also in this study, where students expressed the wish to receive notifications on their mobile, and a proposal that also was made by the administrative staff through the "Vision Statement." The "Vision Statement" for an electronic secretariat that can be achieved through the existence of an electronic protocol, automatic connection with electronic signature and notification of updates to the student's mobile can greatly reduce failures and improve electronic administrative services. The commitment of the institution's leadership is an important factor for improvement of electronic administrative services as noted by the administrative staff and indeed this is a critical success factor for implementation TQM (Zakuan et al., 2012; Sharma et al., 2014).

4.5 Research Question 4: Implementation and Contribution of TQM Tools to Improve the Quality of Electronic Administrative Services

\subsubsection{Students Web Administrative Service}

Ishikawa diagram shows that the failures or the problems identified in the Students web administrative service are due to four main causes: students, administrative staff/secretariat, academic staff and system.

Information from the Ishikawa diagram about the causes was used by FMEA and RPN was calculated for four failures or problems in the administrative service Students web and corrective actions were proposed to reduce the failures.

FMEA shows that the unsuccessful course registration or the mistakes regarding course registration is a problem that has four potential causes of failure, two ways of control and four recommended/corrective actions, one for each potential cause of failure. The delay or non-inclusion of grades in administrative service Students web is a problem that has one potential cause of failure, one way of control and one corrective action. The wrong with diploma supplement is a problem that has one potential cause of failure, two ways of control and one corrective action. The delay or mistakes regarding of the issuing of certificates is a problem that has two potential causes of failure, one way of control and two corrective actions. Additionally, the severity of the effect that problems have on the students and/or on the administrative staff of the secretariat is presented. RPN ranges from 160 to 400 which is the largest. After the corrective actions, RPN ranges from 70 to 240 . The highest (RPN) 400) before the corrective actions, it is due to the weakness of the system. The biggest differences of RPN before and after corrective actions, arise after intervention in the system itself, namely in the electronic administrative service that in this case is administrative service Students web. Smaller differences in RPN before and after corrective actions, which are not negligible, however, are equally important, resulting from corrective actions such as information, students' awareness-raising, recommendations to academic staff, and the internet access throughout university/existence of wi-fi.

In the Pareto analysis, the most vital of the non-vital causes were separated. The limit for considering a failure as significant was above from 340. Six of a total of 10 causes $(60 \%)$ of the most vital failures of the four electronic services, cause problems in the administrative service Students web.

\subsubsection{Administrative Service of Issuing of Academic Identity Cards}

Ishikawa diagram shows that failures or problems identified in administrative service of issuing of academic identity card are due to one main cause: students.

FMEA shows two failures/problems for the administrative service of issuing of academic identity cards. Both problems have a potential cause of failure, two ways of control and a recommended/corrective action that reduces RPN from 126 to 108 . According to Pareto analysis, the RPN of one failure that was detected in this administrative 
service is less than 340 so the failure is non-vital.

\subsubsection{Eudoxos Administrative Service of Academic Books' Registration}

Ishikawa chart shows that the failures or the problems identified in Eudoxos administrative service of academic books' registration are due to two main causes: students and the system.

FMEA shows two failures/problems for the Eudoxos administrative service of academic books' registration, one of which are the mistakes regarding academic books' registration and the other is the unsuccessful academic books' registration. Both problems have five potential causes, three ways of control and five recommended/corrective actions. RPN ranges from 300 to 500, which is the largest. After the corrective actions, RPN ranges from 60 to 300 . The largest RPN (500) is due to a weakness of the system itself. The larger differences of RPN before and after corrective actions are due to interventions in the system itself. The smaller differences, which are equally important differences of RPN before and after corrective actions, are due to students' awareness-raising and the internet access throughout university/existence of wi-fi.

According to Pareto analysis, vital causes of failure are the fact than the administrative staff can't change the list of academic books during the registration RPN (500), the students' lack of familiarity with Eudoxos administrative service RPN (450), the students' lack of accessibility on the Internet RPN (450) and the missing of critical deadlines RPN (400), as they exceed 340 that is the limit for considering a failure as vital. Therefore, four of the ten causes $(40 \%)$ of the most important failures of the four electronic administrative services, cause problems in the Eudoxos administrative service.

\subsubsection{Official Website of the Department}

Ishikawa diagram shows that the failures or the problems in information about students from the website of the department are due to two main causes: students and academic staff.

FMEA for the website of the department shows one failure/problem that is the inadequate/poor information of students from the website that has three potential causes, two ways of control and three recommended/corrective actions. RPN ranges from 245 to 315 which is the largest. The largest RPN (315) has two potential causes, the first is the fact that academic staff doesn't inform administrative staff about course postponement, and the second is the students' lack of accessibility on the Internet. Recommendations to the academic staff as a corrective action for the first cause and the internet access throughout university/existence of wi-fi for the second cause will reduce RPN from 315 to 175 , a reduction of 140 .

According to Pareto analysis, the RPN of the causes of failures that were detected in this administrative service is less than 340 so the failures are non-vital. It is worth noting that students' lack of accessibility on the Internet is a cause of failures that occurs in three of the four services including the website of the department, so a correction of this common cause of failure proposed for the administrative service Students web and Eudoxos administrative service will also benefit this service. The existence of wi-fi for facilitating student access on the Internet is also highlighted by the findings of another relevant research (Bakos, 2013) where students pointed out the need for a wi-fi wireless network.

These findings show that the TQM tools used in this study can help improve the quality of electronic administrative services as they can identify problems and suggest solutions to improve these services. These findings confirm a relevant research (Manola \& Tsarouhas, 2010), which investigated the contribution of TQM tools to improve the quality of administrative services in a higher education institution and showed that the implementation of these tools could show problems, propose solutions and help define procedures that will be useful to improve the quality of the administrative services of a higher education institution. In addition, the above-mentioned findings of the present study confirm the findings of other relevant research, which focused on the study of the results of the implementation of various TQM tools and practices (Korre-Natsi, 2003; Quinn et al., 2009; Ali \& Shastri, 2010; Nyaoga et al., 2010; Manola \& Tsarouhas, 2010; Pilava, 2012; Antoniadou \& Hatzipanayiotou, 2012; Zabadi, 2013; Oluseye et al., 2014; In'airat \& Al-Kassem, 2014; Alzhrami et al., 2016; Saha, 2016) and confirmed the benefits of the implementation of them.

\section{Limitations}

Research limitations include the fact that only the electronic administrative services and not the other services provided by the secretariat were examined. As a second limitation we would note the fact that the University's leadership could have been involved mainly in the part of the "View Statement", so its opinion on TQM and the degree of acceptance could be also have been investigated. 


\section{Conclusions}

The most important administrative service for students is the website of the department, followed by the administrative service Students web, the Eudoxos administrative service of academic books' registration, the administrative service of issuing of academic identity cards, the administrative service of application for housing benefits, and the communication platform uniway for mobiles.

Students are primarily satisfied with course registration in Students web and announcements of program's courses and exams on the official website of the department. They are less satisfied with the announcement of grades on Students web and the Eudoxos administrative service of academic books' registration, even less satisfied with the administrative service of issuing of academic identity cards, the electronic issuing of certificates and the announcements of course postponement at the official website of the department, and lastly the administrative service of application for housing benefits and the communication platform uniway for mobiles.

The most important problem for students is the delay of grades' announcement. Less important problems are the mistakes regarding courses' grades and the unsuccessful course registration and even less important are the delay of the issuing of certificates, the unsuccessful academic books' registration, the mistakes regarding academic books' registration, the unsuccessful issuing of academic identity card, the mistakes regarding course registration, the unsuccessful issuing of certificates and, finally, the mistakes regarding of the issuing of certificates.

Concerning the implementation and contribution of TQM tools to improve the quality of electronic administrative services, there are interesting findings that are analyzed below. From the FMEA and the Pareto diagram, there are ten causes of failure exceeding RPN (340), which is the limit to consider a failure as vital or significant.

Therefore, the causes of failure, as presented in the Ishikawa diagrams include students, administrative staff, academic staff and system that are the electronic administrative service itself. In FMEA, proposed corrective actions are presented and new values of the risk priority number (RPN) are calculated based on the assessment of the researchers. Proposed corrective actions will reduce RPN and failures will have value less than RPN (340) so they will not be significant.

Reducing failures can be achieved through better information of students about the use of electronic administrative services and the existence of wi-fi in the department to facilitate their access to them. Failures whose corrective actions lead to a significant reduction of RPN are related to intervention in the electronic administrative service itself (system weakness).

\section{Proposals for Future}

Proposals for future research could include the following:

- Implementation of TQM tools on other administrative services of the department

- Implementation of TQM with involvement of the leadership of the department.

- Implementation of TQM tools on other electronic services of Primary Education of University of the Aegean such as Moodle.

- Implementation of TQM tools on library's services of the department.

- Implementation of TQM tools on the electronic and non-electronic administrative and educational services of other departments of the University of the Aegean with the participation of a larger number of students, members of the teaching and administrative staff from various departments of the university.

\section{References}

Abdullah, F. (2006). Measuring service quality in higher education: three instruments compared. International Journal of Research \& Method in Education, 29(1), 71-89. https://doi.org/10.1080/01406720500537445

Ali, M., \& Shastri, R. K. (2010). Implementation of total quality management in higher education. Asian Journal of Business Management 2(1). Retrieved from http://maxwellsci.com/print/ajbm/v2-9-16.pdf

Al-Omoush, M. M., Alrahahleh, A. H., \& Alabaddi, Z. A. (2015). Total Quality Management in Higher Education, 5(12). Retrieved from http://www.iiste.org/Journals/index.php/IKM/article/view/27810

Alzhrani, K. M., Alotibie, B. A., \& Abdulaziz, A. (2016). Total Quality Management in Saudi Higher Education. International Journal of Computer Applications, 135(4), 6-12. https://doi.org/10.5120/ijca2016908245

Antoniadou, A., \& Hatzipanayiotou, P. (2012). Total Quality Management in Tertiary Educational Institute of Cyprus: A case study. Proceedings of the 2012 National Conference on Quality in Education: Trends and Perspectives (pp. 632-641). Athens, Greece: National and Kapodistrian University of Athens. 
Argia, H. A., \& Ismail, A. (2013). The Influence of Transformational Leadership on the Level of TQM Implementation in the Higher Education Sector. Higher Education Studies, 3(1), 136-146. https://doi.org/10.5539/hes. v3n1p136

Babbie, E. R. (2011). Introduction to Social Research (G. Vogiatzis, Trans.). Athens: Critical Publications.

Bakos, D.I. (2013). Evaluation of services from students of the University of Patra (Master's thesis, University of Patra, Patra, Greece). Retrieved from http://nemertes.lis.upatras.gr/jspui/handle/10889/8471

Bhalla, R. (2012). Study on Indian Education: A TQM Perspective. International Refereed Social Sciences, 4(2). Retrieved from http://www.researchersworld.com/vol3/issue4/vol3_issue4_2/Paper_03.pdf

Bouris, I. D., \& Dimas, G. (2009). Tracing the degree of satisfaction of students in Higher Education: The case of the Department of Business Administration of TEI of Athens. Review of Economics, 16, 227-250. Retrieved from http://users.teiath.gr/jbouris/JBOURIS1.pdf

Cerri, S. (2014). Electronic service quality in higher education: Evidence from Albania. European Journal of Social Sciences Education and Research, 2(1), 205-211. https://doi.org/10.26417/ejser.v2i1.p205-211

Chua, C. (2004). Perception of quality in higher education. Proceedings of the Australian universities quality forum (pp. 181-187). Melbourne, Australia: AUQA Occasional Publication.

Davies, J. (2008). Integration: Is it the key to effective implementation of the EFQM Excellence Model? International Journal of Quality \& Reliability Management, 25(4), 383-399. https://doi.org/10.1108/02656710810865267

Farooq, M. S., Akhtar, M. S., Ullah, S. Z., \& Memon, R. A. (2007). Application of Total Quality Management in Education. Journal of Quality and Technology Management, 3(2), 87-89. Retrieved from https://files.eric.ed.gov/fulltext/ED506778.pdf

Gika, S. I. (2004). Quality in Higher Education- Organizational Assessment Structures in Europe and Greece (Master's Thesis, University of Piraeus, Piraeus, Greece). Retrieved from http://dione.lib.unipi.gr/xmlui/handle/unipi/285

In'airat, M. H., \& Al-Kassem, A. H. (2014). Total Quality Management in Higher Education: A Review. International Journal of Human Resource Studies, 4(3), 294-307. https://doi.org/10.5296/ijhrs. v4i3.6368

Korre-Natsi, E. (2003). Total Quality of Tourism Education (Master's thesis, University of Piraeus, Piraeus, Greece). Retrieved from http://dione.lib.unipi.gr/xmlui/bitstream/handle/unipi/181/DT2003-0121.pdf? sequence $=1$

Kostitsa, A., \& Spanaka, A. (2013, November). Quality Assurance in Open and Distance Higher Education: An International Record. Proceedings of the 7th International Conference in Open \& Distance Learning, 7, 89-104. http://dx.doi.org/10.12681/icodl.651

Lagrosen, S., Seyyed-Hashemi, R. \& Leitner, M. (2004). Examination of the dimensions of quality in higher education. Quality Assurance in Education, 12(2), 61-69. https://doi.org/10.1108/09684880410536431

Manola, B., \& Tsarouhas, P. (2010, October). Implementing Total Quality Management Systems in Educational Organizations. Case Study: Academic Administration of Department of Logistics of ATEIH. Paper presented at the International Conference in Logistics, Katerini, Greece. Retrieved from http://www.teicm.gr/logistics/images/logisticsdocs/icsc2010/fullabstracts/7_5_ICSC2010_087_Manola_Tsa rouhas.pdf

Militaru, M., Ungureanu, G., \& Chenic, A. Ş. (2013). The prospects of implementing the principles of Total Quality Management (TQM) in education. Procedia-Social and Behavioral Sciences, 93, 1138-1141. https://doi.org/10.1016/j.sbspro.2013.10.003

Nadim, Z. S., \& Al-Hinai, A. H. (2016). Critical Success Factors of TQM in Higher Education Institutions. International Journal of Applied Sciences and Management, 1(2), 147-156. Retrieved from https://www.waljatcollege.edu.om/journal/pdf/Factors-TQM.pdf

Noaman, A. Y., Ragab, A. H. M., Fayoumi, A. G, Khedra, A. M., \& Madbouly, A. I. (2013, September). HEQAM: $A$ developed higher education quality assessment model. Paper presented at the Computer Science and Information Systems Federated Conference, Poland. Abstract retrieved from http://ieeexplore.ieee.org/document/6644091/

Nyaoga, R. B., Nyamwange, O., Onger, R. N., \& Ombati, T. O. (2010). Quality Management Practices in 
Kenyan Educational Institutions: The case of the University of Nairobi. African Journal of Business \& Management, 1, 14-28. Retrieved from http://erepository.uonbi.ac.ke/bitstream/handle/11295/13654/ Magutu_Quality\%20Management\%20practices\%20in\%20Kenyan\%20Educational\%20Institutions.pdf?seq uence $=2$

Oikonomidou, M. E. (2015). Measuring, Evaluating and Improving the Total Quality of the Greek Educational System in a European Framework: Using the Balanced Assessment (Master's thesis, University of Macedonia, Thessaloniki, Greece). Retrieved from https://dspace.lib.uom.gr/bitstream/2159/14275/1/

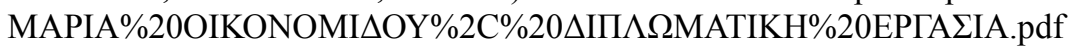

Oluseye, O. O., Borishade, T. T., Adeniyi, S., \& Chinelo, E. I. (2014). An Empirical Analysis of Total Quality Management and Perceived Corporate Image in Higher Education Management. European Scientific Journal, 10(22), 236-250. Retrieved from http://covenantuniversity.edu.ng/Profiles/Sholarin-AdeniyiMuyiwa/AN-EMPIRICAL-ANALYSIS-OF-TOTAL-QUALITY-MANAGEMENT-AND-PERCEIVED-CO RPORATE-IMAGE-IN-HIGHER-EDUCATION-MANAGEMENT

Paraskevopoulos, I. N. (1993). Methodology of Scientific Research. Athens: Greek Letters.

Pilava, P. (2012). The needs/requirements of students of Higher Education Institutions in Cyprus: A Case Study QFD (Master's thesis, University of Piraeus, Piraeus, Greece). Retrieved from http://www.openarchives.gr/view/659205

Quinn, A., Lemay, G., Larsen, P., \& Johnson, D. M. (2009). Service quality in higher education. Total Quality Management, 20(2), 139-152. https://doi.org/10.1080/14783360802622805

Saberi, N., Romle, A. R., \& Hamid, S. N. I. (2015). Proposing the Relationship Between TQM and Service Quality in Public University: A Framework. International Journal of Administration and Governance, 1(4), 111-115. Retrieved from http://repo.uum.edu.my/14311/

Saha, G. (2016). Implementation of total quality management (TQM) in educational institutions. International Education and Research Journal, 2(6), 63-64. Retrieved from http://ierj.in/journal/index.php/ierj/article/view/329

Sharma, S. K., Gupta, S. V., \& Singh, R. (2014). Implementation of TQM for Improving Organizational Effectiveness. International Journal of Application or Innovation in Engineering \& Management, 3(9), 105-110. Retrieved from http://www.ijaiem.org/Volume3Issue9/IJAIEM-2014-09-17-32.pdf

Simeonidou, K. (2015). Total Quality Management in Higher Education. Case Study: The European Model of Excellence Approach (EFQM) in A.U.TH Research Committee (Master's thesis, University of Macedonia, Thessaloniki, Greece). Retrieved from https://dspace.lib.uom.gr/bitstream/2159/16970/3/Symeonidou KonstantiaMsc2015.pdf

Siminou, P. (2011). The European Union's Quality Management Strategy in Higher Education and its implementation in Greece (Master's thesis, University of Macedonia, Thessaloniki, Greece). Retrieved from http://www.openarchives.gr/view/2727735

Soomro, T. R., \& Ahmad, R. (2012). Quality in Higher Education: United Arab Emirates Perspective. Higher Education Studies 2(4), 148-152. https://doi.org/10.5539/ hes.v2n4p148

Tarí, J. J., \& Dick, G. (2016). Trends in quality management research in higher education institutions. Journal of Service Theory and Practice 26(3), 273-296. https://doi.org/10.1108/JSTP-10-2014-0230

Taskov, N., \& Mitreva, E. (2014). The motivation and the efficient communication both are the essential pillar within the building of the TQM (total quality management) system within the Macedonian Higher Education Institutions. Procedia-Social and Behavioral Sciences, 180, 227-234. https://doi.org/10.1016/j.sbspro.2015.02.109

Todorut, A. V. (2013). The need of Total Quality Management in higher education. Procedia-Social and Behavioral Sciences, 83, 1105-1110. https://doi.org/10.1016/j.sbspro.2013.06.207

Tsinidou, M., Gerogiannis, V., \& Fitsilis, P. (2010). Evaluation of the factors that determine quality in higher education: an empirical study. Quality Assurance in Education, 18(3), 227-244. https://doi.org/10.1108/09684881011058669

Zabadi, A. M. (2013). Implementing total quality management (TQM) on the higher education institutions: A conceptual model. Journal of Finance and Economics 1(1), 42-60. https://doi.org/10.12735/jfe.v1ilp42

Zakuan, N., Muniandy, S., Saman, M. Z. M., Ariff, M. S. M., Sulaiman, S., \& Jalil, R. A. (2012). Critical 
Success Factors of Total Quality Management Implementation in Higher Education Institution: A Review. International Journal of Academic Research in Business and Social Sciences, 2(12), 19-32. Retrieved from http://www.hrmars.com/admin/pics/1341.pdf

Zubair, S. S. (2013). Total Quality Management in Public Sector Higher Education Institutions. Journal of
Business
\&
Economics,
$5(1)$,
24-55.
Retrieved
from

https://pdfs.semanticscholar.org/ce4a/154a2bb2e0686dfc9e0f4d4aa6c467364028.pdf

\section{Copyrights}

Copyright for this article is retained by the author(s), with first publication rights granted to the journal.

This is an open-access article distributed under the terms and conditions of the Creative Commons Attribution license (http://creativecommons.org/licenses/by/4.0/). 